\title{
Natural Antioxidant Changes in Fresh and Dried celery (Apium graveolens)
}

\author{
Manal A. Sorour ${ }^{1}$, Naglaa H. M. Hassanen², Mona H. M. Ahmed ${ }^{2}$ \\ ${ }^{1}$ Food Engineering and Packaging Dept., Food Technology Research Institute, Agric. Research Center, Giza, Egypt \\ ${ }^{2}$ Special Food and Nutrition Dept., Food Technology Research Institute, Agric. Research Center, Giza, Egypt
}

Email address:

manal.sorour@yahoo.com (M. A. Sorour),naglaahassaneen@yahoo.com (N. H. M. Hassanen), monahanafiahmed@yahoo.com (M. H. M. Ahmed)

\section{To cite this article:}

Manal A. Sorour, Naglaa H. M. Hassanen, Mona H. M. Ahmed. Natural Antioxidant Changes in Fresh and Dried celery (Apium graveolens). American Journal of Energy Engineering. Special Issue: Energy Conservation in Food Industry. Vol. 3, No. 2-1, 2015, pp. 12-16. doi: 10.11648/j.ajee.s.2015030201.13

\begin{abstract}
The effect of temperature on natural antioxidant changes in fresh and dried celery was studied. Celery herbs were dried at 50 and $90^{\circ} \mathrm{C}$ using a laboratory scale hot air dryer. Fifteen phenolic components (gallic acid, protocatechuic acid, catechol, chlorogenic acid, syringic acid, caffeine , p-coumaric acid, ferulic acid, salycilic acid, cinnamic acid, chrysin, pyrogallol, ellagic acid, catechin and caffeic acid), five flavonoids components were identified in celery herbs (apignen, hesperitin, luteolin, quercetrin and rosmarinic) and three isoflavones components were identified in celery herbs (daidzein, genistein and isorhamnetin) were identified in celery herbs at 50 and $90^{\circ} \mathrm{C}$. The chemical constituents of apium graveolens volatile oil were determined, the results observed that eleven components were isolated from apium graveolens essential oil and classified into five chemical categories namely, monocyclic terpenes $(78.24 \%)$, bicyclic terpenes $(14.88 \%)$, aliphatic hydrocarbons $(1.79 \%)$, ketones $(0.19)$ and sesquiterpene (2.89\%). These identified compounds accounted for $97.99 \%$ of the composition of apium graveolens essential oil. Organoleptic evaluation of Apium graveolens represented the mean scores and their statistical analysis indication for color, aroma, taste, texture and overall acceptability for biscuit treatments mixed with different concentrations of dried Apium graveolens at $50^{\circ} \mathrm{C}$ and $90^{\circ} \mathrm{C}$.
\end{abstract}

Keywords: Drying of Celery, Phenolic Compounds, Flavor, Application of Dried Celery, Flavones

\section{Introduction}

Air-drying is a traditional, low cost technique that is used to lower the water content of herbs at low temperatures. The drying at low temperatures protects against the degradation of the active constituents, but it is slow and metabolic processes may continue longer, which may lead to quality loss of the aromatic plants and subsequently of the produced added value products [1].

Temperature is one of the most important factors affecting antioxidant activity. Generally heating causes an acceleration of the initiation reactions and hence a decrease in the activity of the present or added antioxidants [2].

Phenolics, in particular, are thought to act as antioxidant, anti-carcinogenic, anti-microbial, anti-allergic, antimutagenic and anti-inflammatory, as well as reduce cardiovascular diseases [3].

Flavonoids show a strong antioxidant and radical scavenging activity and appear to be associated with reduced risk for certain chronic diseases, the prevention of some cardiovascular disorders and certain kinds of cancerous processes. Flavonoids exhibit also antiviral, antimicrobial, and anti-inflammatory activities, beneficial effects on capillary fragility and an ability to inhibit human platelet aggregation, antiulcer and antiallergenic properties [4].

Apium graveolens Linn. (Apiaceae) has a long history of use in Ayurveda and Unani system of medicine. Apium graveolens L (Apiaceae) grows wild at the base of the north western himalyas and outlying hills in Punjab and in western India. A. graveolens has been used as a food, and at various times both the whole plant and the seeds have been consumed as a medicine. Celery seeds or celery seed extracts are used as flavoring agents and also in anti rheumatic formulations as the seeds have significance as arthritic pain relief, for treating rheumatic conditions and gout. Apart from the role in rheumatism, celery seeds proved its use in asthma, 
bronchitis and inflammatory conditions [5].

The aim of the work was to study the effect of drying air temperature $\left(50\right.$ and $\left.90^{\circ} \mathrm{C}\right)$ on the quality of celery herbs (phenolic, flavonoids, isoflavones and flavor of apium graveolens), and the evaluation of Apium graveolens when added to biscuits with different concentrations.

\section{Materials and Methods}

\subsection{Materials}

Fresh plant celery (Apium graveolens) was obtained from Agriculture Research Centre, Giza, Egypt during September, 2013.

\subsection{Methods}

\subsubsection{Drying of Celery Herbs}

Drying of celery herbs were carried out using a laboratory scale hot-air dryer installed in Department of Food Engineering and Packaging, Agricultural Research Center at 50 and $90^{\circ} \mathrm{C}$.

\subsubsection{Determination and Identification of Phenolic and Flavonoids Fraction of Celery Herb Using HPLC}

Phenolic and flavonoids fraction compounds were identified determined by the method described by Schieber $e t$ al., 2001 [6]. A high performance liquid chromatography system equipped with a variable wave length detector (Agilant, Germany) 1100, autosampler, quaternary pump degasser and column compartment. Analyses were performed with a C18 reverse phase packed stainless-steel column (Zorbax ODS $5 \mu \mathrm{m} 4.6 \times 250 \mathrm{~mm}$ ). HPLC method started with linear gradient at a flow rate of $1.0 \mathrm{ml} / \mathrm{min}$ with mobile phase of water / acetic acid $(98: 2 \mathrm{v} / \mathrm{v}$, solvent A) and methanol / acetonitril (50:50,v/v, solvent B), starting with $5 \% \mathrm{~B}$ and increasing B to levels of $30 \%$ at $25 \mathrm{~min}, 40 \%$ at $35 \mathrm{~min}, 52 \%$ at $40 \mathrm{~min}, 70 \%$ at $50 \mathrm{~min}, 100 \%$ at $55 \mathrm{~min}$. The initial conditions were re-established by 5 min wash in both solvents. All chromatograms were plotted at $280 \mathrm{~nm}$ to estimated phenolic acids and at $330 \mathrm{~nm}$ for flavonoids. All components were identified and quantified by comparison of peak areas with external standards.

\subsubsection{Determination and Identification of Isoflavones Fraction of Celery Herb Using HPLC}

Isoflavones fraction compounds were determined by the method described by Mantovani et al., 2011 [7]. HPLC Samples of the purified extract had their bulk adjusted with methanol $80 \%$, and filtered in polyethylene filters with PTFE membrane (Millipore Ltd. Bedford, E.U.A.) of $0.45 \mu \mathrm{m}$ pore, before the injection. Isoflavones compounds identification and quantification were carried out through high performance liquid chromatography (Gilson 321), with a secondary pump, deaerator, automatic injector, detector (UV-Visible), and the software program Boriwn version 1.5. The chromatographic conditions described by Song et al. (1998) were used C18 coated column Lichrospher, of Merck ( 250 x 4,6 mm, $5 \mu \mathrm{m}$ ) was used, at $30^{\circ} \mathrm{C}$; mobile phase was constituted of acetic acid and methanol (19:1, v v-1) with $1 \mathrm{~mL}$ min.-1 initial flow; detection at UV-Visible $254 \mathrm{~nm}$; and injection volume of 20 $\mu \mathrm{L}$. The calibration curve was prepared using authentic standards in concentration of 0.25 to $0.1 \mathrm{mg} \mathrm{mL}-1$ diluted in mobile phase.

\subsubsection{Extraction of Essential Oils}

The essential oil of apium graveolens was extracted by water distillation using a (Clevenger-type apparatus) for 4 hours. The obtained volatile oil was dried over anhydrous sodium sulphate and then holds in completely filled a glass bottle at $-20^{\circ} \mathrm{C}$ until use [8].

\subsubsection{Separation and Identification of Essential Oils Constituents}

The GC/MS technique (HP. 5890A) was used to identify the apium graveolens essential oil constituents, under the following conditions: packed capillary column $(50 \mathrm{~m} \times 0.2 \mathrm{~mm} \times 0.3$ thickness film of carbowax $20 \mathrm{M})$, Helium was used as a carrier gas at flow rate $20 \mathrm{~cm} / \mathrm{sec}, \mathrm{HP} 7673 \mathrm{~A}$ automatic injector was used to inject $2.0 \mu \mathrm{L}$ of diluted samples in ethyl alcohol $(1: 10, \mathrm{v} / \mathrm{v})$ with split ratio 100:1, at $150^{\circ} \mathrm{C}$, the oven temperature (programmed) was set at $60^{\circ} \mathrm{C}$ for $10 \mathrm{~min}$ and increasing gradually by the rate of $2.8^{\circ} \mathrm{C} / \mathrm{min}$ to the final temperature $\left(200^{\circ} \mathrm{C}\right)$ during $60 \mathrm{~min}$. Mass spectrum was used to identify the constituents by comparing the samples spectrum with the data stored in Chemstation library which containing over 43,000 compounds.

\subsubsection{Biscuit Preparation}

Biscuits were prepared according to the method reported by Naglaa and Gehad, 2011 [9].

\subsection{Organoleptic Evaluation of Biscuit Matricaria Chamomilla}

The sensory evaluation of the obtained biscuit were carried out by a panel consisted of 10 panelists who asked to evaluate taste, aroma, color, texture and overall acceptability attributes according to the method reported by Amerine et al., 1965 [10]

\subsection{Statistical Analysis}

The obtained results were subjected to statistical analysis using the standard analysis of variance as outlined by Snedecor and Cochran, 1980 [11]

\section{Results and Discussion}

\subsection{Chemical Characteristics of Dried Celery Herbs}

The phenolic, flavonoids and isoflavones of apium graveolens fractionated, and identified by using HPLC.

\subsection{Determination of Phenolic Components}

The phenolic of celery herb are tabulated in Table (1). The results observed that fifteen phenolic components were identified in celery herbs (gallic acid, protocatechuic acid, 
catechol, chlorogenic acid, syringic acid, caffeine, pcoumaric acid, ferulic acid, salycilic acid, cinnamic acid, chrysin, pyrogallol, ellagic acid, catechin and caffeic acid). Meanwhile, celery was dried at $50^{\circ} \mathrm{C}$ and $90^{\circ} \mathrm{C}$ caused detectable decrease in the total contents of the eight phenolic in celery. The increment of protocatechuic acid was (99.84, $64.2 \%)$, catechol was $(150.33,34.74 \%)$, chlorogenic acid was $(31.16,34.96 \%)$, salycilic acid was $(3.10,8.21 \%)$, chrysin was $(313.04,53.68 \%)$, pyrogallol was $(478.97$, $40.11 \%)$ and ellagic acid was $(97.76,60.72 \%)$ at $50^{\circ} \mathrm{C}$ and $90^{\circ} \mathrm{C}$, respectively.

On the other hand, The increment percentages were 427.73 and $45.56 \%$ of gallic acid, 19.70 and $38.76 \%$ of syringic acid, 63.15 and $53.87 \%$ of caffeine, 60.86 and $93.52 \%$ of pcoumaric acid, 48.80 and $95.93 \%$ of ferulic acid, 47.91 and $64 \%$ of cinnamic acid, 68.80 and $61.21 \%$ of catechin and 68 and $50.37 \%$ of caffeic acid for dried celery at $50^{\circ} \mathrm{C}$ and $90^{\circ} \mathrm{C}$, respectively. The obtained data were in harmony with finding of [12-14].

Table (1). Phenolic acids of fresh and dried celery herbs using HPLC (ppm)

\begin{tabular}{llll}
\hline Phenolic acids & Fresh & Dried at $\mathbf{5 0}^{\circ} \mathbf{C}$ & Dried at $\mathbf{9 0}^{\circ} \mathbf{C}$ \\
\hline Gallic & 20.85 & 110.45 & 160.78 \\
Protocatechuic & 90.50 & 35.76 & 12.77 \\
Catechol & 7.53 & 18.85 & 25.40 \\
Chlorogenic & 65.30 & 85.65 & 115.60 \\
Syringic & 25.22 & 20.25 & 12.40 \\
Caffeine & 6.65 & 2.45 & 1.13 \\
P-Coumaric & 17.76 & 6.95 & 0.45 \\
Ferulic & 16.80 & 8.60 & 0.35 \\
Salycilic & 3.54 & 3.65 & 3.95 \\
Cinnamic & 0.48 & 0.25 & 0.09 \\
Chrysin & 0.23 & 0.95 & 1.46 \\
Pyrogallol & 75.26 & 435.74 & 610.54 \\
Ellagic & 235.56 & 465.85 & 748.75 \\
Catechin & 18.43 & 5.75 & 2.23 \\
Caffeic & 4.22 & 1.35 & 0.67 \\
\hline
\end{tabular}

\subsection{Determination of Flavonoids Components}

Flavonoids constitute the largest group of plant phenols and account for over half of the 8000 naturally occurring phenolic compounds [15].

Table (2). Flavonoids of fresh and dried celery herbs using HPLC (ppm)

\begin{tabular}{llll}
\hline Components & Fresh & Dried at $\mathbf{5 0}^{\mathbf{}} \mathbf{C}$ & Dried at $\mathbf{9 0}^{\circ} \mathbf{C}$ \\
\hline Apignen & 94.74 & 97.68 & 104.74 \\
Hesperitin & 92.76 & 136.54 & 194.65 \\
Luteolin & 43.45 & 76.48 & 110.26 \\
Quercetrin & 110.35 & 574.82 & 993.27 \\
Rosmarinic & 96.58 & 43.66 & 19.82 \\
\hline
\end{tabular}

The flavonoids of dried celery herb are tabulated in Table (2). The results observed that five flavonoids components were identified in celery herbs (apignen, hesperitin, luteolin, quercetrin and rosmarinic). Celery was dried at $50^{\circ} \mathrm{C}$ and $90^{\circ} \mathrm{C}$ caused detectable increase in the total contents of the four flavonoids. The increment percentages were $(3.1,7.22 \%)$ for apignen, $(47.19,42.55 \%)$ for hesperitin, $(76.01,44.16 \%)$ for luteolin and $(420.90,72.79 \%)$ for quercetrin at $50^{\circ} \mathrm{C}$ and $90^{\circ} \mathrm{C}$, respectively. Meanwhile, the decrement percentages were $(54.79,54.60 \%)$ for rosmarinic at $50^{\circ} \mathrm{C}$ and $90^{\circ} \mathrm{C}$, respectively. The obtained data were in harmony with finding of Wach et al, [16].

\subsection{Determination of Isoflavones Components}

The isoflavones of dried celery herb are tabulated in Table (3). The results observed that three isoflavones components were identified (daidzein, genistein and isorhamnetin). Celery was dried at $50^{\circ} \mathrm{C}$ and $90^{\circ} \mathrm{C}$ caused detectable increase in the total contents of the two isoflavones. The increment percentages were $(136.47,96.42 \%)$ for genistein and $(96.94,82.45 \%)$ for isorhamnetin at $50^{\circ} \mathrm{C}$ and $90^{\circ} \mathrm{C}$, respectively. Moreover, the decrement percentages were $(37.61,39.95 \%)$ of daidzein at $50^{\circ} \mathrm{C}$ or $90^{\circ} \mathrm{C}$, respectively. The obtained data were in harmony with finding of Manal and Sahar [13]

Table (3). Isoflavones of fresh and dried celery herbs using HPLC (ppm)

\begin{tabular}{llll}
\hline Components & Fresh & Dried at $\mathbf{5 0}^{\circ} \mathbf{C}$ & Dried at $\mathbf{9 0}^{\circ} \mathbf{C}$ \\
\hline Daidzein & 1820.45 & 1135.72 & 681.92 \\
Genistein & 30.84 & 72.93 & 143.25 \\
Isorhamnetin & 484.32 & 953.85 & 1671.36 \\
\hline
\end{tabular}

\subsection{Chemical Composition of Essential Oil}

Essential oils of food products affect their nutritional availability due to their direct responsibility for consumer acceptance or rejection. Thus, the changes occurred in the chemical composition of the essential oil of two collective samples of celery dried at $50^{\circ} \mathrm{C}$ and $90^{\circ} \mathrm{C}$.

The percent of essential oil for fresh celery was $0.72 \%$, the obtained data are in harmony with the findings of Fazal and Singla [5]. The chemical constituents of apium graveolens volatile oil are tabulated in Table (4). From these results, it could be indicated that eleven components were isolated from apium graveolens essential oil. These components were identified and classified into five chemical categories namely monocyclic terpenes $(78.24 \%)$, bicyclic terpenes $(14.88 \%)$, aliphatic hydrocarbons (1.79\%), ketones (0.19) and sesquiterpene $(2.89 \%)$. The percent of these identified compounds were $97.99 \%$ of apium graveolens essential oil and the remainder portion was $2.01 \%$ representing seven unknown constituents. The first chemical group as shown in Table (4) was monocyclic terpenes which consists of two compounds (d-Limonene, $77.65 \%$ and $\gamma$-terpinine, $0.59 \%$ ). Limonene was reported as the major constituent of apium graveolens essential oil by Misic et al., and Fazal \& Singla [5 and 17]. The second recorded chemical group was bicyclic terpenes which consists of four components $n$ ( $\alpha$-pinene, $1.36 \%$, camphene, $0.29 \%$, Sabinen, $1.72 \%$ and $\beta$-pinene, $11.55 \%$. The third identified chemical group was aliphatic hydrocarbons which consists of one compound ( $\beta$ - myercene, $1.79 \%$ ). This compound was reported as constituent of apium graveolens essential oil by Misic et al., 2008 [17]. The fourth identified chemical group was ketones which consist of one compound (L-carvone, $0.19 \%$ ). The five chemical group was sesquiterpene which consists of three compounds ( $\beta$ caryophyllene, $1.11 \%, \beta$-selinene, $0.93 \%$ and $\alpha$ - selinene 


\section{$0.85 \%)$.}

The results observed that dried celery at $50^{\circ} \mathrm{C}$ and $90^{\circ} \mathrm{C}$ caused detectable decrease in the total contents of five chemical groups. The percent of monocyclic terpenes was decreased to $(5.77,11.37 \%),(27.75,41.66 \%)$ for bi-cyclic terpenes, $(20.67,50.27 \%)$ for aliphatic hydrocarbons, $(42.10$, $63.15 \%)$ for ketones and $(19.03,41.17 \%)$ for sesquiterpene at $50^{\circ} \mathrm{C}$ and $90^{\circ} \mathrm{C}$, respectively. The obtained data were in harmony with finding of Okoh et al., 2008 [18]

Table (4). Chemical components of celery (apium graveolens) essential oils fractionated and identified by GC/Mass technique.

\begin{tabular}{|c|c|c|c|}
\hline \multirow{2}{*}{ Chemical compounds } & \multicolumn{3}{|c|}{ Area \% } \\
\hline & fresh & $50^{\circ} \mathrm{C}$ & $90^{\circ} \mathrm{C}$ \\
\hline \multicolumn{4}{|l|}{ 1-Monocyclic terpenes: } \\
\hline d-Limonene & 77.65 & 73.34 & 69.13 \\
\hline$\gamma$-terpinene & 0.59 & 0.38 & 0.21 \\
\hline Total : & 78.24 & 73.72 & 69.34 \\
\hline \multicolumn{4}{|l|}{ 2-Bi cyclic terpenes: } \\
\hline$\alpha$-pinene & 1.36 & 0.97 & 0.75 \\
\hline Camphene & 0.29 & 0.15 & 0.08 \\
\hline Sabinen & 1.72 & 1.45 & 1.22 \\
\hline$\beta$-pinene & 11.51 & 8.18 & 6.63 \\
\hline Total : & 14.88 & 10.75 & 8.68 \\
\hline \multicolumn{4}{|l|}{ 3-Aliphati hydrocarbons: } \\
\hline$\beta$-Myercene & 1.79 & 1.42 & 0.89 \\
\hline Total : & 1.79 & 1.42 & 0.89 \\
\hline \multicolumn{4}{|l|}{ 4- Ketones: } \\
\hline L-Carvone & 0.19 & 0.11 & 0.07 \\
\hline Total: & 0.19 & 0.11 & 0.07 \\
\hline \multicolumn{4}{|l|}{ 5-Sesquiterpene: } \\
\hline$\beta$-Caryophyllen & 1.11 & 0.90 & 0.77 \\
\hline$\beta$-selinene & 0.93 & 0.78 & 0.54 \\
\hline$\alpha$-selinene & 0.85 & 0.66 & 0.39 \\
\hline Total: & 2.89 & 2.34 & 1.70 \\
\hline 6-Unknown: & 2.01 & 11.66 & 19.32 \\
\hline
\end{tabular}

\subsection{Organoleptic Evaluation of Celery (apium graveolens)}

Table (5) represents the mean scores and their statistical analysis indication for color, aroma, taste, texture and overall acceptability for biscuit treatments mixed with different concentrations of dried celery (apium graveolens) herbs at $50^{\circ} \mathrm{C}$ and $90^{\circ} \mathrm{C}$. The data in Table (5) indicated that there are no significant differences in the quality attributes i.e., texture of biscuit which manufactured with or without (control) addition of different levels of apium graveolens. According to the results, the mean score of aroma, taste and overall acceptability of biscuit samples increased as the concentration of apium graveolens increased from 0.1 to $0.3 \%$. Therefore, high significant differences were found among these samples and their control sample. However, no significant differences were found in the acceptability among all biscuit samples incorporated different concentrations of apium graveolens dried at $90^{\circ} \mathrm{C}(0.1,0.2$ and $0.3 \%)$. On the other hand, the biscuit samples formulated with $0.1 \%, 0.2 \%$ and $0.3 \%$ of apium graveolens dried at $50{ }^{\circ} \mathrm{C}$ had higher aroma and taste scores in comparison with biscuit samples of the control and celery dried at $90^{\circ} \mathrm{C}$. The obtained data are in harmony with the findings of Lawiess and Naglaa \& Gehad, [13 and 19]
Table (5). The mean scores of organoleptic evaluation of biscuits manufactured by addition of dried celery apium graveolens herbs at $50^{\circ} \mathrm{C}$ and $90^{\circ} \mathrm{C}$.

\begin{tabular}{|c|c|c|c|c|c|c|}
\hline Treatments & Color & Aroma & Taste & Texture & $\begin{array}{l}\text { Overall } \\
\text { quality }\end{array}$ & $\begin{array}{l}\text { Accept } \\
\text { ability }\end{array}$ \\
\hline Control & $10.0^{\mathrm{a}}$ & $7.0^{\mathrm{d}}$ & $7.0^{\mathrm{d}}$ & $9.0^{\mathrm{a}}$ & $8.0^{\mathrm{e}}$ & + \\
\hline \multicolumn{7}{|c|}{ Dried celery at $50^{\circ} \mathrm{C}$} \\
\hline \multicolumn{7}{|l|}{ Apium } \\
\hline $\begin{array}{l}\text { graveolens } \\
(0.1 \%)\end{array}$ & $9.0^{\mathrm{b}}$ & $9.0^{\mathrm{b}}$ & $9.0^{\mathrm{b}}$ & $8.0^{\mathrm{b}}$ & $9.00^{\mathrm{b}}$ & +++ \\
\hline \multicolumn{7}{|l|}{ Apium } \\
\hline $\begin{array}{l}\text { graveolens } \\
(0.2 \%)\end{array}$ & $9.0^{\mathrm{b}}$ & $10.0^{\mathrm{a}}$ & $10.0^{\mathrm{a}}$ & $8.0^{\mathrm{b}}$ & $9.50^{\mathrm{a}}$ & ++++ \\
\hline $\begin{array}{l}\text { Apium } \\
\text { graveolens } \\
(0.3 \%)\end{array}$ & $8.0^{\mathrm{c}}$ & $10.0^{\mathrm{a}}$ & $10.0^{\mathrm{a}}$ & $8.0^{\mathrm{b}}$ & $9.50^{\mathrm{a}}$ & ++++ \\
\hline \multicolumn{7}{|c|}{ Dried celery at $90^{\circ} \mathrm{C}$} \\
\hline Apium & & & & & & \\
\hline $\begin{array}{l}\text { graveolens } \\
(0.1 \%)\end{array}$ & $8.0^{\mathrm{c}}$ & $8.0^{\mathrm{c}}$ & $8.0^{\mathrm{c}}$ & $8.0^{\mathrm{b}}$ & $8.0^{\mathrm{e}}$ & ++ \\
\hline Apium & & & & & & \\
\hline $\begin{array}{l}\text { graveolens } \\
(0.2 \%)\end{array}$ & $7.0^{\mathrm{d}}$ & $9.0^{\mathrm{b}}$ & $9.0^{\mathrm{b}}$ & $8.0^{\mathrm{b}}$ & $8.5^{\mathrm{cd}}$ & ++ \\
\hline Apium & & & & & & \\
\hline $\begin{array}{l}\text { graveolens } \\
(0.3 \%)\end{array}$ & $7.0^{\mathrm{d}}$ & $9.0^{\mathrm{b}}$ & $9.0^{\mathrm{b}}$ & $8.0^{\mathrm{b}}$ & $8.5^{\mathrm{cd}}$ & ++ \\
\hline LSD & 0.01779 & 0.02516 & 0.0251 & 0.00562 & 0.03081 & \\
\hline
\end{tabular}

$(+)$ The sample is acceptable.

$(+++)$ The sample is very good acceptable.

$(++)$ The sample is good acceptable.

$(++++)$ The sample is excellent acceptable.

*Any two means, at the same column, have the same letter did not

significantly different at $5 \%$ or $1 \%$ level of probability.

\section{Conclusion}

Celery herbs were dried at 50 and $90^{\circ} \mathrm{C}$ using a laboratory scale hot air dryer and the phenolic, flavonoids and isoflavones of apium graveolens fractionated, and identified by using HPLC. Drying of celery herbs at $50^{\circ} \mathrm{C}$ and $90^{\circ} \mathrm{C}$ caused detectable decrease in the total contents of the eight phenolic acids (protocatechuic, catechol, chlorogenic, salycilic, chrysin, pyrogallol and ellagic acid), while it caused an increment in the total content of gallic, syringic, caffeine, p-coumaric, ferulic, cinnamic, catechin and caffeic. Five flavonoids components were identified in celery herbs (apignen, hesperitin, luteolin, quercetrin and rosmarinic) and three isoflavones components were identified (daidzein, genistein and isorhamnetin) in dried celery herbs. The chemical constituents of apium graveolens volatile oil were determined, the results observed that eleven components were isolated from apium graveolens essential oil and classified into five chemical categories namely, monocyclic terpenes, bicyclic terpenes, aliphatic hydrocarbons, ketones and sesquiterpene. Organoleptic evaluation of Apium graveolens represented the mean scores and their statistical analysis indication for color, aroma, taste, texture and overall acceptability for biscuit treatments mixed with different concentrations of dried Apium graveolens at $50^{\circ} \mathrm{C}$ and $90^{\circ} \mathrm{C}$. 


\section{References}

[1] M. Keinänen and R. Julkunen-Tiitto, Effect of sample preparation method on birch (Betula pendula Roth leaf phenolics, Journal of Agricultural and Food Chemistry, 44: 2724-2727, 1996.

[2] J. Pokorny, Addition of antioxidants for food stabilization to control oxidative rancidity, Czech Journal of Food Sciences, 4: 299-307, 1986

[3] D.O. Kim, S.W. Jeong and C. Y. Lee, Food Chem. 81:321-326, doi:10.1016/S0308-8146(02)00423-5, 2003

[4] G. Giuseppe, B. Davide, G. Claudia, Ugo Leuzzi and C. Corrado: Flavonoid Composition of Citrus Juices. Molecules, $12,1641-1673,2007$

[5] S. S. Fazal and R. K. Singla, Review on the Pharmacognostical \& Pharmacological Characterization of Apium Graveolens Linn. Indo Global, Journal of Pharmaceutical Sciences, 2(1): 36-42, 2012.

[6] A. Schieber, P. Keller, R. Carle, Determination of phenolic acids and flavonoids of apple and pear by high performance liquid chromatography system, J. of Chromatography A, 910:265-273, 2001.

[7] D. Mantovani, L. C. Filho, L. C. Santos, V.L.F. de Souza and C.S. Watanabe, The use of HPLC identification and quantification of isoflavones content in samples obtained in pharmacies. Acta Scientiarum. Biological Sciences. Maringá, v. 33, n. 1, pp. 7-10, 2011.

[8] M. Guenther, The essential oils, Vol. III, IV, 4th Ed. D. Van Nostrand Company, Inc. Princeton, New Jersy. Tornto, New York, London, 1961.

[9] Naglaa H.M. Hassanen and Gehad, F.A.Fath El-bab. Antimicrobial activities of Matricaria chamomilla L. flower. Egypt. J. Biomed. Sci., 37: 189-211, 2011.

[10] M. A. Amerine, R. M. Panglorn, and Roessler, E. B. (): Principals of sensory evaluation of food"Academic Press, New York, 1965.

[11] G.W. Snedecor and W.G. Cochran, Statistical methods. $7^{\text {th }}$ Ed., p. 420. Iowa Stat. Univ. Press, Ames, Iowa, USA, 1980.
[12] A. Crozier, B. J. Indu and N. Michael, Dietary phenolics: chemistry, bioavailability and effects on health. Nat. Prod. Rep., 26, 1001-1043, 2009.

[13] M. S. M. Manal and S. A. Sahar, The Effects of Purslane and Celery on Hypercholesterolemic Mice, World Journal of Dairy \& Food Sciences, 7 (2): 212-221, 2012.

[14] Liga Priecina and Daina Karklina, Natural Antioxidant Changes in Fresh and Dried Spices and Vegetables, International Journal of Biological, Veterinary, Agricultural and Food Engineering Vol. 8, No. 5, 480-484, 2014.

[15] N. Balasundram, K. Sundram and S. Samman, Phenolic compounds in plants and agri-industrial by-products: Antioxidant activity, occurrence, and potential uses, Food Chemistry, 99, 191- 203, 2006.

[16] A. Wach, K. Pyrzyn'ska and Magdalena Biesaga, Quercetin content in some food and herbal samples. Food Chemistry $100: 699-704,2007$.

[17] Misic Dusan, Irena Zizovic, Marko Stameni, Ruzica Asanin, Mihailo Risti, Slobodan Petrovi and Dejan Skala, Antimicrobial activity of celery fruit isolates and SFE process modeling Biochemical Engineering Journal, 42, 148-152, 2008 .

[18] O. O. Okoh, A. P. Sadimenko, O. T. Asekun and A. J. Afolayan, The effects of drying on the chemical components of essential oils of Calendula officinalis L. African Journal of Biotechnology Vol. 7 (10), pp. 1500-1502, 2008.

[19] Lawiess and Julia, The Encyclopaedia of essential oils.Published in Great Britain in 1992 by Element Books Limited Longmead, Shaftesbury, Dorset, pp.81-84 and 103105, 1992.

[20] Van Wassenhove, F., Dirinck, P., Vulsteke, G. and Schamp, N., Aromatic volatile composition of celery and celeriac cultivars. Hort. Sci., 25, 556-559, 1990

[21] Fazal, S. S., Ansari, M. M., Singla, R. K., Khan, S., Isolation of 3-n-Butyl Phthalide \& Sedanenolide from Apium graveolens Linn. Indo Global Journal of Pharmaceutical Sciences, 2(3): 258-261, 2012. 